\title{
Requirement for maintenance and gain of crude protein for two genotypes of growing quails ${ }^{1}$
}

\author{
José Jordão Filho², José Humberto Vilar da Silva ${ }^{3}$, Fernando Guilherme Perazzo Costa ${ }^{4}$, Luiz \\ Fernando Teixeira Albino ${ }^{5}$, Thiago de Sousa Melo ${ }^{6}$, Patrícia Barbosa de Lacerda ${ }^{7}$, Gabriela \\ Mafra Dantas ${ }^{8}$, Rejane Pontes Soares ${ }^{6}$
}

\author{
${ }^{1}$ Projected financed by CNPq. \\ 2 Doutorado Integrado em Zootecnia, CCA/UFPB/UFRPE/UFC. DAP/CCHSA/UFPB, Bananeiras - PB \\ ${ }^{3}$ PDIZ/CCA/UFPB, Areia - PB and PPGTA/CCHSA/UFPB, Bananeiras - PB. Researcher from CNPq-1B. \\ ${ }^{4}$ PDIZ/CCA/UFPB, Areia - PB. Researcher from CNPq, level 2. \\ ${ }^{5}$ Departamento de Zootecnia, UFV, Viçosa - MG \\ ${ }^{6}$ Mestrado em Tecnologia Agroalimentar, CCHSA/UFPB. \\ ${ }^{7}$ Mestrado em Zootecnia, PPGZ/CCA/UFPB. \\ ${ }^{8}$ Doutorado Integrado em Zootecnia, CCA/UFPB/UFRPE/UFC.
}

\begin{abstract}
The objective of this study was to estimate the requirements for maintenance and gain of crude protein in Japanese and European quails aged 16-36 days. To determine the maintenance requirements, one experiment was conducted in a completely randomized design with four decreasing feeding levels (100, 75, 50 and 25\%) and four replicates per treatment. The method of comparative slaughter was used, through a feeding assay. A total of 352 quails from each strain were housed by supply level in 16 pens measuring $1.0 \times 1.5 \mathrm{~m}$, totaling 22 birds per cage under ambient temperature conditions $\left(26 \pm 0.5^{\circ} \mathrm{C}\right)$. To estimate the requirement gains, one experiment was conducted with five groups of quails fed ad libitum and housed under controlled temperature of $18{ }^{\circ} \mathrm{C}$. All poultry were slaughtered at 16, 21, 26, 31 and 36 days of testing for determination of body composition in protein throughout growth. The requirement for maintenance of the Japanese quail differs from that obtained with the European quail. The protein was retained at the proportion of 32\% for European quails and $25 \%$ for the Japanese quails. This difference in retention promoted estimate of $0.65 \mathrm{~g} / \mathrm{g}$ gain in European quails and $0.84 \mathrm{~g} / \mathrm{g}$ gain in Japanese quails. Quails should be fed diets formulated considering the requirement for protein of each genotype.
\end{abstract}

Key Words: growth, modeling, protein, quail genotypes

\section{Introduction}

Commercially raised quails have two geographical origins: one group was bred in Asia, for egg production and the other in Europe, for meat production (Silva \& Costa, 2009). According to Silva et al. (2007), differences in the nutrition of Japanese and European quails are similar to those between broilers and laying hens, in which diets formulated for a species should not be used in the feeding of others.

Considering the absence of studies to comparatively assess the changes in mass and body composition of quail genotypes in the growth phase, Silva \& Costa (2009) applied the Gompertz curve and estimated the highest rate of daily weight gain at 28 days of age for both quail species, but the European ones had greater weight at maturity and higher rate of gain in the growth phase. Again, Silva \& Costa (2009) reported that European quails are more demanding in protein than the Japanese ones. Results of Jordão Filho et al. (2011) showed that European quails also required more energy for maintenance and were more efficient in energy use for gain than the Japanese ones.

Healthy animals under growth use basically the metabolizable protein to meet the requirements of maintenance and gain, but the efficiency with which these functions are met depends on many internal and external factors to the animal body, among which is the quail genotype (Jordão Filho et al., 2011). Meeting all requirements under varying conditions of genetics, climatic environment and housing has justified the development of prediction models.

Considering that the commercial production of quails should prioritize the optimization of the dietary protein conversion into body protein (lean meat) and egg production, errors in the protein concentration of feeds may diminish the economic and productive performance of poultry. Excess protein increases the oxidation of amino acid as source of energy and nitrogen excretion, whereas the deficiency 
increases the catabolism of tissue protein and fat from the poultry carcass. Therefore, the protein unbalance in the diet increases the activity of key enzymes in the catabolism of amino acids (Yuan \& Austic, 2001). This is because the excess in amino acids in the bloodstream is toxic to the animal organism, so there must be quick removal, usually by the liver, catabolism and excretion of nitrogen ingested above the body needs (Nelson \& Cox, 2011).

Thus, the objective of the present study was to estimate the protein requirements for maintenance and gain of European and Japanese quails during the growth period of 16 to 36 days of age.

\section{Material and Methods}

The experiment was conducted at the Laboratory of Poultry Nutrition Research at the Centro de Ciências Humanas, Sociais e Agrárias of UFPB, located in the city of Bananeiras, Paraíba, Brazil.

Estimates of maintenance requirements and weight gain in crude protein were determined in two commercial quail genotypes (Japanese and European) in the period of 16-36 days of age.

The requirement for maintenance was estimated in one experiment with 352 quails of each genotype, weighted at 16 days and distributed by weight range in 16 pens of $1.5 \mathrm{~m}^{2}$ $(1.0 \times 1.5 \mathrm{~m})$ with 22 poultry each. Pens were equipped with a drinker, feeder, incandescent bulbs of $60 \mathrm{~W}$ and the floor was covered with litter shavings. The poultry received natural and artificial light for 24 hours and the mean temperature in the shed was $26 \pm 0.5^{\circ} \mathrm{C}$.

The design was completely randomized, with decrease of the feed supply level based on ad libitum intake (100, 75,50 and $25 \%$ ). The consumption level of $25 \%$ was determined by the prediction model proposed by Silva et al. (2004ab), so that poultry consumed nutrients below the maintenance requirement. The diet was formulated based on corn and soybean meal (Table 1), as recommended by Silva \& Costa (2009).

The requirement of protein for maintenance was estimated by the comparative slaughter methodology. A group of 50 quails of each genotype was slaughtered at 16 days of age (slaughter reference) and all quails of the plots at 36 days of age, assuming that the body composition of the initial slaughter group represented the body composition of the whole population (Wolynetz \& Sibbald, 1987). The reference group of 50 birds was chosen based on the standard deviation of $\pm 5 \%$ from the average live weight of quails at 16 days of age, composing weight of $67.7 \pm 4 \mathrm{~g}$ for Japanese quails and $93.1 \pm 5 \mathrm{~g}$ for European quails.
After solid fasting of 24 hours, quails were weighed for measurement of the empty body weight, and then killed by cervical dislocation, avoiding the loss of blood and feathers to enable the evaluation of the nutrient deposition in the body.

The empty body of each bird was identified and stored in a freezer. It was then triturated in cutter-type meat grinder three consecutive times, removing a representative sample. These samples were weighed and placed in forced-ventilation oven at $55^{\circ} \mathrm{C}$ for 72 hours to pre-drying. Later, they were again ground in cutter two consecutive times and once in Willey-type mill and conducted to laboratory for the analytical determinations, according to Silva \& Queiroz (2002).

The dry matter of samples was obtained after drying in oven with ventilation and forced air circulation at $105{ }^{\circ} \mathrm{C}$ for 4 hours, and the crude protein by Kjeldahl method. Lipids were extracted by immersing the samples in hexane Soxhlet apparatus, and the mineral matter by burning the sample in oven at $600{ }^{\circ} \mathrm{C}$ for 4 hours. The gross energy was determined by Parr type adiabatic calorimeter bomb.

Table 1 - Feed and nutritional composition of experimental diets ${ }^{1}$

\begin{tabular}{|c|c|c|}
\hline \multirow{2}{*}{ Ingredient } & \multicolumn{2}{|c|}{ Diet $(\mathrm{kg})$} \\
\hline & Japanese quails & European quails \\
\hline Corn & 54.774 & 65.615 \\
\hline Soybean meal & 41.619 & 29.624 \\
\hline Limestone & 1.452 & 0.656 \\
\hline Dicalcium phosphate & 1.250 & 1.050 \\
\hline DL-methionine & 0.170 & 0.264 \\
\hline L-threonine & 0.019 & 0.000 \\
\hline Salt & 0.342 & 0.441 \\
\hline Choline chloride & 0.050 & 0.050 \\
\hline Vitamin premix ${ }^{2}$ & 0.100 & 0.100 \\
\hline Mineral premix ${ }^{3}$ & 0.050 & 0.050 \\
\hline Butylated hydroxytoluene & 0.010 & 0.010 \\
\hline Inert (washed sand) & 0.164 & 2.140 \\
\hline \multicolumn{3}{|c|}{ Chemical composition } \\
\hline Crude protein $(\%)$ & 23.500 & 19.000 \\
\hline $\begin{array}{l}\text { Apparent metabolizable } \\
\text { energy }(\mathrm{kcal} / \mathrm{kg})\end{array}$ & 2800.000 & 2900.000 \\
\hline Calcium (\%) & 0.980 & 0.600 \\
\hline Available phosphorus (\%) & 0.375 & 0.300 \\
\hline Arginine (\%) & 1.605 & 1.249 \\
\hline Lysine $(\%)$ & 1.294 & 0.987 \\
\hline Methionine $(\%)$ & 0.532 & 0.565 \\
\hline Methionine + cystine $(\%)$ & 0.900 & 0.880 \\
\hline Threonine $(\%)$ & 0.940 & 0.743 \\
\hline Tryptophan (\%) & 0.303 & 0.232 \\
\hline Valine (\%) & 1.100 & 0.893 \\
\hline Sodium (\%) & 0.160 & 0.200 \\
\hline Potassium (\%) & 0.930 & 0.748 \\
\hline Chlorine (\%) & 0.252 & 0.310 \\
\hline
\end{tabular}

${ }^{1}$ Recommendations of Silva \& Costa (2009).

2 Product composition/kg: vit. A - 10,000,000 IU; vit D3 - 2,500,000 IU; vit. E $15,000 \mathrm{mg}$; vit. K - 2,000 mg; vit. B1 - 2,000 mg; vit. B2 - 4,000 mg; vit. B6 - 4.000 mg; vit. B12 - 15,000 mg; vit. C - 50,000 mg; niacin - 30,000 mg; biotin - $60 \mathrm{mg}$; folic acid - $500 \mathrm{mg}$; pantothenic acid - 16,000 mg; BHT - $125 \mathrm{mg}$.

${ }^{3}$ Product composition/kg: Zn - 110,000 mg; Se - 360 mg; I - 1,400 mg; Cu - 20,000 mg; $\mathrm{Mn}-156,000 \mathrm{mg}$; Fe - 96,000 mg. 
The protein retained in the poultry body of each plot was calculated as the difference between the amount of protein in the empty body of poultry slaughtered at the end of the experiment and the amount present in the poultry body of the reference slaughter. The maintenance requirements were determined by linear regression of protein retained in the empty body according to protein intake. The line intercept with the $\mathrm{X}$ axis was interpreted as a requirement for protein dietary maintenance, while the regression coefficient (parameter "b") indicated the efficiency of protein utilization for weight gain.

To determine the net protein requirement for weight gain of Japanese and European quails, poultry from the initial and final slaughters were used, in a group of 90 quails, which was slaughtered in three intermediate phases. Each intermediate group consisted of three replicates of ten quails slaughtered at 21, 26 and 31 days of age. These groups of poultry were reared and fed the experimental diet, according to the methodology described by Silva et al. (2004ab). Animals were housed in climatic chamber with controlled temperature of $18.6 \pm 0.6^{\circ} \mathrm{C}$. Feed intake, poultry weight, weight gain and subsequently, protein retention in the empty body, in addition to proximal composition similar to the analytical and bromatological procedures conducted on samples of the maintenance group were determined.

The net protein requirement for weight gain was estimated by regressing the retained protein according to the empty body weight of quails in five slaughter periods $(16,21,26,31$ and 36 days); parameter "b" was the net requirement itself, in $\mathrm{g} / \mathrm{g}$ of crude protein for gain, while the dietary requirement for gain was calculated by the relationship between net protein requirement and utilization efficiency determined in the trial for maintenance.

\section{Results and Discussion}

The crude protein intake declined as the feed supply dropped to $25 \%$ of ad libitum feeding, affecting protein retention in poultry (Table 2). Although protein intake varies little between genotypes, the European quails were more efficient in retaining the protein intake compared with the Japanese ones at the level of $50 \%$, but when $25 \%$ of ad libitum feeding was offered, European quails showed negative balance of protein, while the Japanese showed positive balance.

The difference in nutritional balance between European and Japanese quails is exactly similar to that observed between broilers and laying hens in which each genotype has specific requirement for each nutrient and corroborates the suggestion of Silva et al. (2007), that diets formulated for a quail species should not be used in feeding other species. Silva \& Costa (2009) showed that European quails had higher rate of daily gain and higher weight at maturity than the Japanese quails. These differences were confirmed by comparing the results of weight gain of Japanese quails from $2.76 \mathrm{~g} / \mathrm{hen} /$ day of $1-12$ days of age (Silva et al., 2004a) with the weight gain of European quails $3.27 \mathrm{~g} / \mathrm{hen} /$ day of 1-14 days of age (Rezende et al., 2004).

European quails had higher protein requirement for maintenance than the Japanese ones (Figure 1). This result confirms the suggestion of Silva \& Costa (2009), that European quails are more demanding in protein than the Japanese for maintenance. The protein requirement for maintenance of Japanese quails $\left(4.78 \mathrm{~g} / \mathrm{kg}^{0.75} / \mathrm{day}\right)$ was similar to the $4.75 \mathrm{~g} / \mathrm{kg}^{0.75} /$ day estimated for Japanese quails by Silva et al. (2004b) in the period between 15-32 days of age.

The intercept of the linear regression equation for body protein retention depending on the protein intake (Figure 1) resulted in an endogenous protein estimate by 1.22 and $1.55 \mathrm{~g} / \mathrm{kg}^{0.75} /$ day for Japanese and European quails, respectively. The European genotype showed metabolic and endogenous losses of nitrogen $\left(248 \mathrm{mg} / \mathrm{kg}^{0.75} /\right.$ day) higher than the Japanese strain $\left(195 \mathrm{mg} / \mathrm{kg}^{0.75} /\right.$ day); however, the values were within the recommendation of Scott et al. (1982), with loss of approximately $250 \mathrm{mg}$ nitrogen $/ \mathrm{kg}$ body weight. According to these authors, the endogenous metabolism and digestive tract consists of saliva, gastric juice, pancreatic juice, desquamation of epithelial cells of the intestinal mucosa and mucins that are produced and secreted by cells throughout the gastrointestinal tract. Differences in nitrogen losses reflect, possibly, changes in retention and genetics of each quail species.

Protein was retained in the proportion of 25 and $32 \%$ protein intake by European and Japanese quails, respectively. These values were lower than those obtained with replacement pullets aged 42-63 days (55\%), estimated by Albino et al. (1994), however, they remained above the $23 \%$ estimated for Japanese quails aged 15-32 days (Silva et al., 2004b). The use efficiency of dietary crude

Table 2 - Protein intake and retention in the empty body and respective standard deviations of Japanese and European quails according to the level of feed supply

\begin{tabular}{lcccc}
\hline $\begin{array}{l}\text { Feed } \\
\text { supply } \\
(\%)\end{array}$ & \multicolumn{2}{c}{ Japanese quails } & \multicolumn{2}{c}{ European quails } \\
\cline { 2 - 5 } & $\begin{array}{c}\text { Crude protein } \\
\text { intake }(\mathrm{g} / \mathrm{d})\end{array}$ & $\begin{array}{c}\text { Protein } \\
\text { retained }(\mathrm{g} / \mathrm{d})\end{array}$ & $\begin{array}{c}\text { Crude protein } \\
\text { intake }(\mathrm{g} / \mathrm{d})\end{array}$ & $\begin{array}{c}\text { Protein } \\
\text { retained }(\mathrm{g} / \mathrm{d})\end{array}$ \\
\hline 100 & $6.01 \pm 0.04$ & $1.24 \pm 0.03$ & $6.02 \pm 0.03$ & $1.43 \pm 0.06$ \\
75 & $4.55 \pm 0.04$ & $0.95 \pm 0.02$ & $4.27 \pm 0.03$ & $0.97 \pm 0.04$ \\
50 & $3.42 \pm 0.03$ & $0.51 \pm 0.02$ & $2.90 \pm 0.05$ & $0.62 \pm 0.04$ \\
25 & $1.44 \pm 0.03$ & $0.11 \pm 0.01$ & $1.41 \pm 0.03$ & $-0.07 \pm 0.03$ \\
\hline
\end{tabular}


a)
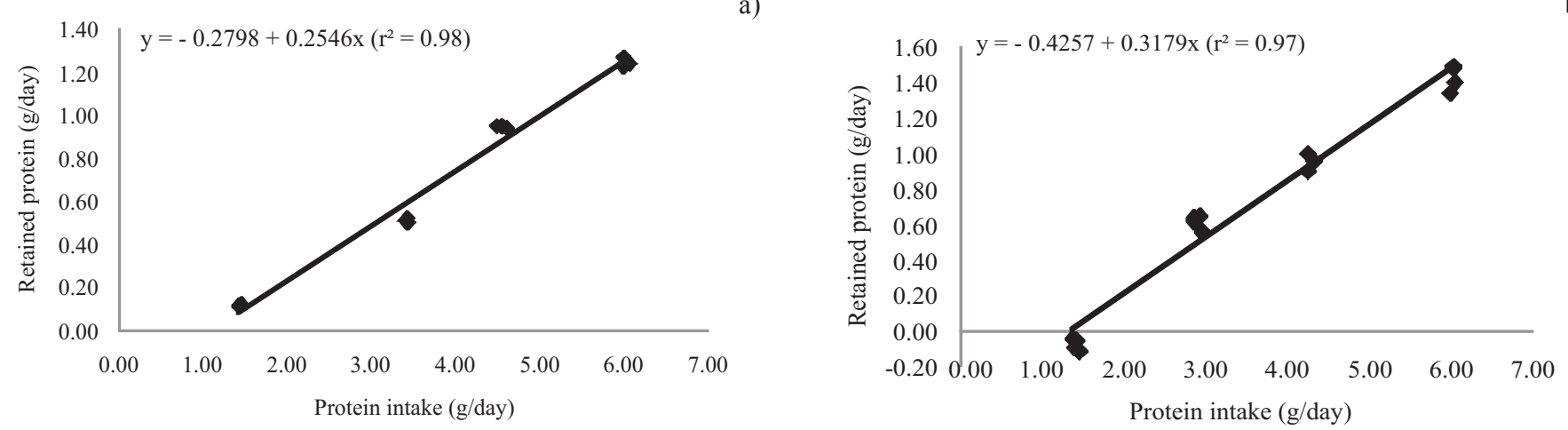

Figure 1 - Regression equation of crude protein retained according to protein intake with efficiencies of utilization for gain of 0.25 and $0.32 \%$ and maintenance requirements of 4.78 and $4.86 \mathrm{~g} / \mathrm{kg}^{0.75} /$ day for Japanese (a) and European (b) quails, respectively.

protein by poultry is affected by many factors such as gender, age (Samadi \& Liebert, 2006), disease, nutritional status, protein balance, presence of antinutritional factors, feed wastage and poultry genotype (Jordão Filho et al., 2011). Thus, different quail genotypes retain crude protein in the carcass at different rates and less efficiently compared with other avian species such as broilers and laying hens. Comparing the nutritional requirements of quails with chickens, Silva \& Costa (2009) concluded that quails require more protein and amino acids in the diet. The lower retention rate helps explain the variations in the protein requirements of quails compared with other avian species and confirms the hypothesis of Silva et al. (2007), that poultry should be fed diets formulated considering the requirement of each genotype.

To gain, there were variations in body weight and crude protein content of the empty body of both quail genotypes (Table 3). Similar net protein requirements were estimated for both quail species at approximately $0.21 \mathrm{~g}$ of crude protein/g gain (Figure 2); however, the dietary requirement for protein gain was 30\% higher for Japanese quails compared with the European (0.84 vs. $0.65 \mathrm{~g}$ of crude protein/g gain), due to their being less efficient in the use of dietary protein to gain than European quails ( 0.32 versus $0.25 \%$ ). These results show that animals with the same net requirement may have different dietary requirements for the same nutrient.

Despite the net requirement per gram of gain being close and European quails having lower dietary protein requirement per gram of the gain than the Japanese, European quails need to ingest lower amounts of protein daily (Figure 3) to ensure higher rates of daily weight gain (Figure 4).

Differences in protein gain in the empty body of quails began to take shape from the third week of age (Figure 4) and increased after 21 days of age, following the trend observed in a study on the weight gain curve (Silva \& Costa, 2009). At the end of the growth period studied, the European quails showed protein deposition in empty body about $56 \%$ higher than the value observed in the Japanese strain, explaining the greater efficiency in the deposition of protein intake by European quails.

Knowledge of these differences in dietary requirements between both quail species helps in the decision to define protein levels in the diet for each of them. Hyánková \& Knízetová (2009), studying females and males of two strains of Japanese quails selected for high and low weight gain, concluded that the former were very sensitive to the low crude protein content of the diet with lower growth rate from the first to the six weeks of life in comparison with the genotype selected for the low rate of gain. The authors suggested that from the onset, quails selected for high body gain needed to consume higher amounts of protein compared with poultry of slow growth.

Table 3 - Average weight, crude protein and body protein in the empty body of Japanese and European quails according to age

\begin{tabular}{|c|c|c|c|}
\hline $\begin{array}{l}\text { Age } \\
\text { (days) }\end{array}$ & $\begin{array}{c}\text { Empty body } \\
\text { weight (g) }\end{array}$ & $\begin{array}{c}\text { Crude } \\
\text { protein }(\%)\end{array}$ & $\begin{array}{c}\text { Body crude } \\
\text { protein }(g / g)^{1}\end{array}$ \\
\hline \multicolumn{4}{|c|}{ Japanese quails } \\
\hline 16 & 67.71 & 16.85 & 11.41 \\
\hline 21 & 91.31 & 20.68 & 18.88 \\
\hline 26 & 113.86 & 20.93 & 23.83 \\
\hline 31 & 133.73 & 19.71 & 26.36 \\
\hline 36 & 146.88 & 19.38 & 28.46 \\
\hline \multicolumn{4}{|c|}{ European quails } \\
\hline 16 & 93.15 & 17.19 & 16.01 \\
\hline 21 & 130.20 & 19.20 & 25.00 \\
\hline 26 & 154.93 & 20.35 & 31.53 \\
\hline 31 & 192.40 & 19.72 & 37.94 \\
\hline 36 & 227.25 & 19.60 & 44.54 \\
\hline
\end{tabular}

${ }^{1}$ Body protein was obtained by the product of crude protein with the empty body weight. 
a)
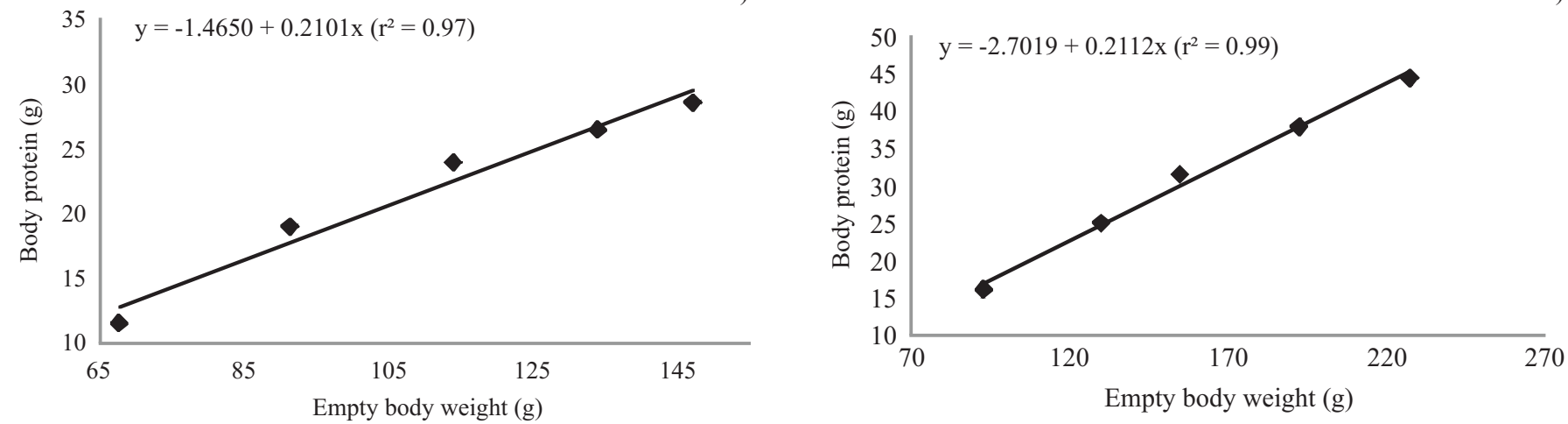

Figure 2 - Body protein according to the empty body weight, with the gain requirement of $0.84 \mathrm{~g} / \mathrm{g}$ in Japanese (a) and $0.65 \mathrm{~g} / \mathrm{g}$ in European (b) quails.

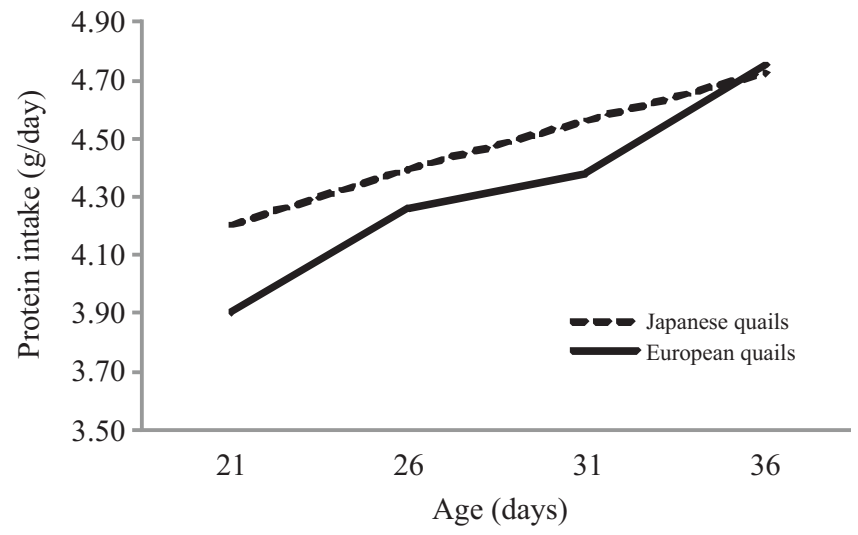

Figure 3 - Protein intake according to the age of both quail genotypes.

New evidence has shown (Silva \& Costa, 2009) that the highest rate of daily weight gain in both genotypes occurs at approximately 28 days of age, but the gain is $85 \%$ higher in the European quails in comparison with the Japanese (7.6 vs. 4.1 g/day weight gain); therefore, European quails have higher body deposition rate than Japanese. Among Japanese quail species, but with different genetic characteristics, Hyánková \& Knízetová (2009) estimated, by the Richard curve, higher weight at maturity, higher rate of weight maturation and higher weight at the peak of maturity (inflection point) of quail strains selected for high gain compared with quails improved for low growth, despite the latter being about seven days earlier.

Estimates of dietary protein requirements for gain of Japanese $(0.84 \mathrm{~g} / \mathrm{g})$ and European $(0.65 \mathrm{~g} / \mathrm{g})$ quails were above $0.31 \mathrm{~g} / \mathrm{g}$ of gain estimated for Lohmann pullets aged between 42 and 63 days (Albino et al., 1994) due to the lower use efficiency for protein deposition in the body.

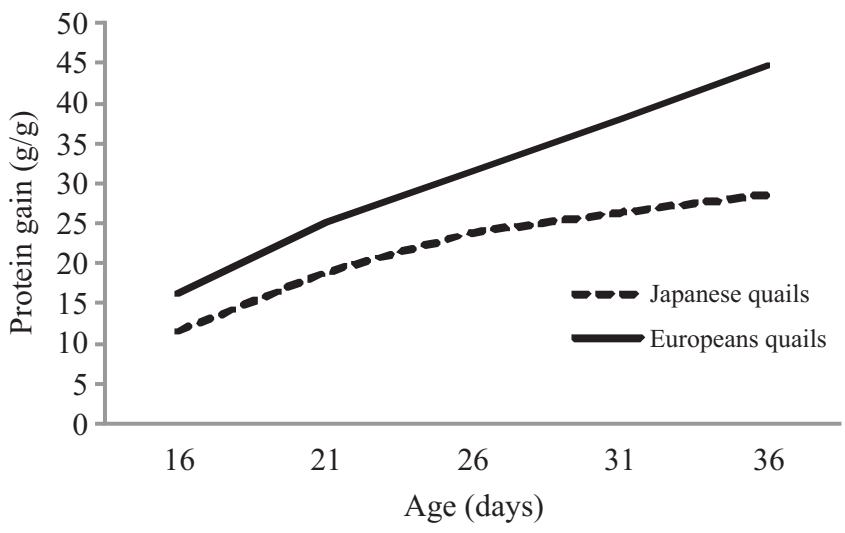

Figure 4 - Protein gain according to the age of both quail genotypes.

Lower protein retention by quails in comparison with the pullets was also observed by Silva et al. (2004b), working with Japanese quails aged between 15 and 32 days. This shows that there are differences between poultry species in the protein requirement for gain. In a study with broiler breeders, Filardi et al. (2000) found $0.45 \mathrm{~g}$ of protein gain for the phase between 15 and 20 weeks, estimate above 0.34 and $0.40 \mathrm{~g} / \mathrm{g}$ protein gain for stages from 3 to 8 and 9 to 14 weeks of age, respectively. With Japanese quails, 0.46 to $0.84 \mathrm{~g} / \mathrm{g}$ protein gain was determined for the period 1-12 and 15 to 32 days of age by Silva et al. (2004a,b), arguing that the increased requirement of protein gained by the proximity of position is assigned to a lower use efficiency of protein with increasing age. On the other hand, Samadi $\&$ Liebert (2006) found that the daily nitrogen deposition in broilers increased with poultry age so that it reduced the estimate of 3.45 to $2.60 \mathrm{mg} \mathrm{N} / \mathrm{kg}^{0.67} /$ day at the phase $10-25$ to 30-45 days of age, respectively. 
Table 4 - Nutritional plan of Japanese and European quails for protein and energy

\begin{tabular}{|c|c|c|c|c|c|c|c|c|}
\hline \multirow{2}{*}{ Body weight (g) } & \multirow{2}{*}{$\begin{array}{l}\text { Weight gain } \\
\text { (g/day) }\end{array}$} & \multirow{2}{*}{$\begin{array}{c}\text { Metabolic } \\
\text { weight }\left(\mathrm{kg}^{0.75}\right)\end{array}$} & \multicolumn{3}{|c|}{ Protein requirement (g/day) } & \multirow{2}{*}{$\begin{array}{c}\text { Energy } \\
\text { requirement } \\
(\mathrm{kcal} / \mathrm{day})^{1}\end{array}$} & \multicolumn{2}{|c|}{$\begin{array}{c}\text { Feed intake }(\mathrm{g} / \text { day }) \text { - Crude } \\
\text { protein }(\%)\end{array}$} \\
\hline & & & Maintenance & Gain & Total & & $2800 \mathrm{kcal} \mathrm{ME}$ & $2900 \mathrm{kcal} \mathrm{ME}$ \\
\hline \multicolumn{9}{|c|}{ Japanese quails } \\
\hline 80 & 0.0 & 0.150 & 0.72 & 0 & 0.72 & 14.42 & $5.15(14)$ & $4.97(14)$ \\
\hline 120 & 2.0 & 0.204 & 0.97 & 1.68 & 2.65 & 37.54 & $13.41(20)$ & $12.95(21)$ \\
\hline 160 & 4.0 & 0.253 & 1.21 & 3.36 & 4.57 & 60.25 & $21.52(21)$ & $20.78(22)$ \\
\hline 100 & 0.0 & 0.178 & 0.86 & 0 & 0.86 & 19.05 & $6.81(13)$ & $6.57(13)$ \\
\hline 140 & 2.0 & 0.229 & 1.11 & 1.3 & 2.41 & 43.96 & $15.70(15)$ & $15.16(16)$ \\
\hline 180 & 4.0 & 0.276 & 1.34 & 2.6 & 3.94 & 68.49 & $24.46(16)$ & $23.62(17)$ \\
\hline 220 & 6.0 & 0.321 & 1.56 & 3.9 & 5.46 & 92.74 & $33.12(16)$ & $31.98(17)$ \\
\hline
\end{tabular}

ME - metabolizable energy.

Japanese quail: crude protein for maintenance $=4.78 *$ metabolic weight; crude protein gain $=0.84 *$ weight gain.

European quail: crude protein for maintenance $=4.86 *$ metabolic weight; crude protein gain $=0.65 *$ weight gain

${ }^{1}$ Jordão Filho et al. (2011).

The combination of protein requirement estimates using the prediction equations of this study with the estimates of metabolizable energy requirements set in Jordão Filho et al. (2011) enabled the simulation of nutrition plans for European and Japanese quails (Table 4), in which the former require more dietary protein by the lower efficiency of protein deposition. Feed with higher energy density should contain more protein due to the lower consumption. Assuming increasing weight gains in quails, the higher the desired weight gain the higher the amount of feed, protein and energy to be fed to poultry.

The results of this study confirm the suggestions of Silva \& Costa (2009) about superior protein contents for European quails than for Japanese, whereas there are differences in protein requirements between the two genotypes improved for laying and meat production. The use efficiency of protein for maintenance of metabolic processes and growth depends on the poultry genotype, in which poultry with the greatest potential for growth would be theoretically more efficient using the diet nutrients. The differences in requirements for maintenance and weight gain for both quail genotypes corroborate the statement of Silva et al. (2007), that diets formulated to a quail species should not be used in feeding other species, similar to what happens to broilers and laying hens.

\section{Conclusions}

The prediction models to estimate the crude protein requirements utilized in this study result in higher maintenance requirement for European quails and higher gain demand for Japanese quails.

\section{Acknowledgements}

The authors thank CNPq for financing the project and Capes for granting the scholarship.

\section{References}

ALBINO, L.F.T.; FIALHO, F.B.; BELLAVER, C. et al. Estimativas das exigências de energia e proteína para frangas de postura em recria. Pesquisa Agropecuária Brasileira, v.29, p.1625-1629, 1994.

FILARDI, R.S.; SAKOMURA, N.K.; BASAGLIA, R. et al. Equação de predição das exigências de proteína bruta para matrizes pesadas em crescimento. Revista Brasileira de Zootecnia, v.29, n.6, p.2308-2315, 2000.

HYÁNKOVÁ, L.; KNIZETOVÁ, H. Divergent selection for shape of growth curve in Japanese quail. 5. Growth pattern and low protein level in starter diet. British Poultry Science, v.50, p.451-458, 2009.

JORDÃO FILHO, J.; SILVA, J.H.V.; SILVA, C.T. et al. Energy requirement for maintenance and gain for two genotypes of quails housed in different breeding rearing systems. Revista Brasileira de Zootecnia, v.40, n.11, p.2415-2422, 2011.

NELSON, D.L.; COX, M.M. Princípios de bioquímica de Lehninger. 5.ed. Savier: ArtMed, 2011. 1274p.

REZENDE, M.J.M.; FLAUZINA, L.P.; McMANUS, C. et al. Desempenho produtivo e biometria das vísceras de codornas francesas alimentadas com diferentes níveis de energia metabolizável e proteína bruta. Acta Scientiarum Animal Sciences, v.26, n.3, p.353-358, 2004.

SAMADI, F.; LIEBERT, F. Estimation of nitrogen maintenance requirements and potential for nitrogen deposition in fastgrowing chickens depending on age and sex. Poultry Science, v.85, p.1421-1429, 2006.

SCOTT, M.L.; NESHEIM, M.C.; YOUNG, R.J. Nutrition of the chicken. 3.ed. Ithaca: M.L. Scott, 1982. 562p.

SILVA, D.J.; QUEIROZ, A.S. Análise de alimentos: métodos químicos e biológicos. 3.ed. Viçosa, MG: UFV, 2002. 235p.

SILVA, J.H.V.; COSTA, F.G.P. Tabelas para codornas japonesas e europeias: tópicos especiais, composição de alimento e exigências nutricionais. 2.ed. Jaboticabal: FUNEP, 2009. 107p.

SILVA, J.H.V.; COSTA, F.G.P.; SILVA, E.L. et al. Exigências nutricionais de codornas. In: CONGRESSO INTERNACIONAL 
DE COTURniCUltura, 3., 2007, Lavras. Palestra... Lavras: UFLA, 2007. p.42-62.

SILVA, J.H.V.; SILVA, M.B.; JORDÃO FILHO, J. et al. Exigências de mantença e de ganho de proteína e de energia em codornas japonesas (Coturnix coturnix japonica) na fase de 1 a 12 dias de idade. Revista Brasileira de Zootecnia, v.33, n.5, p.1209-1219, 2004a.

SILVA, J.H.V.; SILVA, M.B.; JORDÃO FILHO, J. et al. Exigências de mantença e de ganho em proteína e energia em codornas japonesas (Coturnix coturnix japonica) na fase de 15 a 32 dias. Revista Brasileira de Zootecnia, v.33, n.5, p.1220-1230, 2004b.

YUAN, J.H.; AUSTIC, R.E. The effect of dietary protein level on threonine dehydrogenase activity in chickens. Poultry Science, v.80, p.1353-1356, 2001.

WOLYNETZ, M.S.; SIBBALD, I.R. Need for comparative slaughter experiments in poultry research. Poultry Science, v.66, p.1961-1972, 1987. 